\title{
Predicting big sagebrush winter forage by sub- species and browse form class
}

\author{
C.L. WAMBOLT, W.H. CREAMER, AND R.J. ROSSI
}

Authors are professor and research assistant, Department of Animal and Range Sciences, Montana Statc University, Bozeman 59717; and assistant professor. Department of Statistics. Cal Poly. San Luis Obispo 93403.

\section{Abstract}

Improved regression models were developed to predict winter forage production from big sagebrush (A rtemisia tridentata Nutt.) through consideration of the subspecies variation among mountain big sagebrush (A.t. ssp. vaseyana [Rydb.] Beetle), Wyoming big sagebrush (A.t. ssp. wyomingensis Beetle and Young), and basin big sagebrush ( $A$.t. ssp. tridentata). Changes in shrub morphology from browsing were also accommodated in our models. Colinearities among some variables used in previous studies were found and avoided in our models. Models used easily measured objective variables of which major axis and average cover of shrubs were most useful. Multivariable models without colinearities were evaluated on the basis of their $R_{2}^{2}$ values which increased by an average of $10 \%$ to near 0.90 , with taxa and browse form class included, compared to a model ignoring these differences.

Key Words: Artemisia tridentata, big-game browse, modeling forage production

Big sagebrush (Artemisia tridentata Nutt.) provides cover and forage for a variety of wildlife. Elk (Cervus elaphus nelsoni) and mule deer (Odocoileus hemionus) browse mountain big sagebrush (A.t. ssp. vaseyana [Rydb.] Beetle), Wyoming big sagebrush (A.t. ssp. wyomingensis Beetle and Young), and basin big sagebrush (A.t. ssp. tridentata) heavily from autumn through early spring throughout most of their distribution. Differences in growth form, distribution, ecology, phenology, animal preference, and forage qualities are well defined among these big sagebrush subspecies (Beetle 1960, Winward 1970, Kelsey et al. 1976, Morris et al. 1976, Harvey 1981, Welch and Pederson 1981, Personius et al. 1987, Striby et al. 1987, Wambolt and McNeal 1987).

A nondestructive procedure to predict the forage produced by subspecies within the big sagebrush complex would be helpful in determining carrying capacity for browsing wildlife, in detecting trends in forage production, and in measuring plant response to management. Harvest sampling methods are costly, time consuming, and damage plants (Uresk et al. 1977). Nondestructive procedures to estimate production have been developed for a variety of other plants (Pechanec and Pickford 1937, Weaver 1977, Andrew et al. 1979) and should be feasible for big sagebrush.

Previous modeling of forage production from big sagebrush has not considered production differences between subspecies nor plants with different browsing histories that affect shrub morphology (Hughes et al. 1987). Neither has colinearity among independent variables used in past modeling been considered.

Our objective was to develop regression models using objective, easily measured plant dimensions that avoid colinearity problems to accurately predict winter forage production for mountain,

Research was funded by the Montana Agricultural Experiment Station (J-2825).

Manuscript accepted 31 Dec. 1993.
Wyoming, and basin big sagebrush. We considered the potential influence of past browsing in our models.

\section{Methods}

\section{Study Area}

The study area is located near Gardiner in the Gallatin National Forest of southwestern Montana. Gardiner lies in the Yellowstone River valley at $1,694 \mathrm{~m}$ surrounded by peaks reaching $3,353 \mathrm{~m}$. Average annual precipitation over 100 years is $412 \mathrm{~mm}$ at Gardiner. The rain shadow produced by the mountains makes the benches and slopes an important wintering area for mule deer and elk, while bison, bighorn sheep, and antelope also use some portions of the area.

Vegetation is predominantly sagebrush-grassland (Wambolt and McNeal 1987). The 3 subspecies of big sagebrush we studied and black sagebrush (Artemisia nova A. Nels.) occur sympatrically throughout the study area. Browsing of big sagebrush has been heavy enough on the study area to result in reduction of the taxa (Patten 1993).

\section{Measurements}

Six big sagebrush stands were sampled: high-use Wyoming big sagebrush (ATWH), low-use Wyoming big sagebrush (ATWL), high-use mountain big sagebrush (ATVH), low-use mountain big sagebrush (ATVL), high-use basin big sagebrush (ATTH), and low-use basin big sagebrush (ATTL). Variation in browsing levels over many years by elk and mule deer on different portions of the study area have resulted in very distinct growth forms between low and high-use plants, which is described in detail by Personius et al. (1987) and Striby et al. (1987).

Sampling was conducted in August and September of 1989. This allowed for the nearly complete abscission of the ephemeral leaves, which are not considered available winter browse. Only the current crop of perennial leaves persists over winter (Miller and Schultz 1987). Thirty shrubs were sampled at each of 6 sites in a proportion equal to the number of different sized shrubs at each site.

Overall height (HT) of each sagebrush plant was measured from the ground to the highest nonreproductive foliage. Because we were interested in forage available to deer and elk, the maximum plant height was set at $140 \mathrm{~cm}$. Plants of basin big sagebrush that exceeded this limit were not sampled.

Several measurements of crown width were taken (Rittenhouse and Sneva 1977). The major axis (MJ) was the maximum horizontal distance across the plant crown inclusive only of living plant tissue. The minor axis (MN) was the maximum crown width perpendicular to the MJ, again only for living tissue. Canopy cover (AC) (Canfield 1941) was derived by measuring the crown with 2 additional perpendicular axes at $45^{\circ}$ to the intersection of the $\mathrm{MJ}$ and $\mathrm{MN}$ axes and then averaging the 4 measurements. Although photosynthetic tissue was used for the end points of these axes, dead crown, and canopy openings were included. 
Crown depth (CD) was the vertical distance of the portion of the crown foliated by vegetative leaders (Dean et al. 1981). Several measurements, depending on plant size, were averaged for each plant.

Seedheads were clipped at the base, counted for each plant, and oven dried for 48 hours at $60^{\circ} \mathrm{C}$ before weighing to the nearest 0.1 g. Average seedhead weight was calculated as the weight of the seedheads divided by the number of seedheads.

Forage weight $(F)$ was the dependent variable for the regression analysis. After obtaining the measurements above, perennial leaves and current twig growth were removed from the plant. Young twigs were easily discernible on the basis of color, texture of the bark, and leaf bud scars. Although browsing ungulates may remove secondary growth, we considered only current year production. After oven-drying for 48 hours at $60^{\circ} \mathrm{C}$ the foliage was weighed to the nearest $0.1 \mathrm{~g}$.

The field measurements above were used to derive other variables for the regression analysis. Elliptical canopy area was determined by the formula $\mathrm{E}=\pi(\mathrm{MJ} / 2) *(\mathrm{MN} / 2)$. Crown volume was then defined as $\mathrm{CV}=\mathrm{E}^{*} \mathrm{CD}$. Shrub volume was defined as $\mathrm{SV}=$ E*HT. Peek (1970) and Harvey (1981) refer to this variable as crown volume.

The crowns of heavily browsed plants appeared more rounded than those of lightly browsed plants, so circular crown areas were considered (Murray and Jacobson 1982). Two variables that represent circular area of the canopy were investigated: (1) the circular area $(\mathrm{Cl})$ for the major axis from the formula, $\mathrm{Cl}=\pi$ $(\mathrm{MJ} / 2)^{2}$, and (2) the circular area (C2) for the minor axis from the formula $\mathrm{C} 2=\pi(\mathrm{MN} / 2)^{2}$.

\section{Statistical Analysis}

Regression models were evaluated on the basis of their adjusted $R^{2}$ values, $R_{\mathrm{a}}^{2}=1-(n-1) /(n-p-1)^{*}\left(1-R^{2}\right)$ (Neter et al. 1985), where $n$ is sample size and $p$ is the number of independent variables in the model. The $R_{\mathrm{a}}^{2}$ is based on the coefficient of determination $\left(R^{2}\right)$; however, unlike $R^{2}, R_{\mathrm{a}}^{2}$ penalizes models that include variables that do not reduce the prediction error. Using the $R_{\mathrm{a}}^{2}$ statistic to evaluate the models prevents models with artificially high $R^{2}$ values from being considered. In most cases, the values of $R_{\mathrm{a}}^{2}$ are similar to the values of $R^{2}$, athough somewhat smaller. Furthermore, the model with the highest $R_{\mathrm{a}}^{2}$ will also be the model with the smallest root mean squared error (RMSE).

Scatter plots of each independent variable versus the dependent variable (F) were constructed to identify linear and curvilinear trends. Height (HT) for ATVL was the only variable determined to have a curvilinear relationship with the dependent variable $(F)$ and thus, $\mathrm{HT}^{2}$ was included for consideration in the models predicting ATVL.

Forage (F), the dependent variable, was log transformed (natural logarithm) to stabilize nonconstant variance exhibited in the residual plots. Nonconstant variance was a direct result of stratified random sampling used to obtain a representative sample of different-sized shrubs at each site.

Colinearity analysis for each taxon and form class combination identified colinearities among some variables (Creamer et al. 1992). Major axis (MJ) and minor axis (MN) were determined to be nearly colinear with each other and also with elliptical canopy area (E) caused by the consistently similar shape of the crowns. Information contained in each of the 3 variables is nearly identical, thus including more than 1 of these 3 variables in a model is inappropriate (Neter et al. 1985). To avoid the problems caused by the colinearities, 3 groups of independent variables were formed. Each group consisted of 1 of the variables $M J, M N$, or $E$ along with the remaining independent variables. Regression models are of the form: $\ln (F)=a+b_{1} X_{1}+b_{2} X_{2}+b_{3} X_{3}+b_{4} X_{4}+b_{5} X_{5}+b_{6} X_{6}+b_{7} X_{7}+b_{8} X_{8}+e$

where

$$
\begin{aligned}
& F=\text { available winter forage } \\
& a=y \text {-intercept } \\
& X_{1}=M J \text { or } M N \text { or } E \\
& X_{2}=H T \\
& X_{3}=H^{2} \\
& X_{4}=C D \\
& X_{5}=A C \\
& X_{6}=C 1 \text { or } C 2 \text { or } C V \\
& X_{7}=S V \\
& X_{8}=A S \\
& e=\text { residual error }
\end{aligned}
$$

Each of the 3 groups of independent variables was fit to regression models regardless of taxa or browsing history. These regression models were compared to models which account for differences in taxa and browse form class. An extra sums of squares $F$ test was conducted to test for differences among the 6 taxa and browse form class combinations (Neter et al. 1985). If the extra sums of squares $F$ test detected differences among the 6 taxa and form class combinations, the data from each site were to be used to determine a model for its corresponding taxon and form class.

\section{Results and Discussion}

The 3 variable groups based on major axis $(\mathrm{MJ})$, minor axis (MN), or elliptical canopy area (E) had similar $R_{a}^{2}$ values (Creamer et al. 1992). That is, each variable group predicts annual winter forage production for all 3 subspecies and 2 form classes of big sagebrush with essentially the same efficiency. Thus, we decided that the logical criterion to determine the best variable group for suggested usage should be the ease of measuring the variables used in the regression model. Because models using MJ have this advantage, they are presented in Table 1.

The regression model based on the 8 predictor variables which ignores taxa and form class has $R=0.82$ and $R M S E=0.38$. In comparison, the model which accounts for taxa and form class has $R_{z}=0.90$ and $\mathrm{RMSE}=0.28$. The extra sums of squares $F$ test detected significant $(P<0.0001)$ differences among the models for the 6 taxa and form class combinations. Therefore, models were built separately for each taxon and form class combination with a subsequent increase in $R_{a}^{2}$ values that averages $10 \%$.

In addition to regression models that most accurately predict (highest $R_{\mathrm{a}}^{2}$ ) winter forage production of big sagebrush taxa, we have included efficiency models and best single variable models in Table 1 . The efficiency models have nearly as high $R_{a}^{2}$ values as the highest $R_{\mathrm{a}}^{2}$ models and, therefore, could be recommended under most circumstances for use by resource managers. The efficiency models retain most of the precision obtained from the highest $R_{\mathrm{a}}^{2}$ models, but require fewer measurements and calculations. Single variable models may also suffice for some purposes with minimal effort required for their use. For example, the single variable model for high-use basin big sagebrush (ATTH) based on canopy cover (AC) has an $R$ ? $=0.84$ in comparison with the highest multivariable model having an $R_{\text {a }}=0.88$ (Table 1).

The addition of average seedhead weight (AS) does increase $R$ for low-use mountain big sagebrush (ATVL), low-use Wyoming big sagebrush (ATWL), and low-use basin big sagebrush (ATTL) and decreases the RMSE (Table 1). For high-use mountain big sagebrush (ATVH) and high-use basin big sagebrush (ATTH), AS contributed no increase in $R_{\mathrm{a}}^{2}$ and the increases for high-use Wyoming big sagebrush (ATWH) are very small. This is logical as heavily used plants produced few inflorescences. Consequently, the addition of this variable to the model is most meaningful for predicting forage production for low use plants. 
Table 1. Highest $R$ l regression models with and without $\mathbf{A S}^{\wedge}$, efficiency model, and best single variable model. All multi-variable models have used MJ and excluded $M N$ and $E$ to avoid colinearity problems.

\begin{tabular}{|c|c|c|c|c|}
\hline \multicolumn{5}{|c|}{$\begin{array}{l}\text { Taxon and form } \\
\text { class }\end{array}$} \\
\hline \multicolumn{5}{|c|}{ Highest $R_{\mathrm{a}}^{2}$ models with AS } \\
\hline ATVL & $\ln (F)=.65+.380(\mathrm{AS})+.029(\mathrm{AC})+.038(\mathrm{MJ})-.0002(\mathrm{Cl})$ & .90 & .91 & .33 \\
\hline ATVH & $\ln (F)=.31+.047(\mathrm{AC})+.037(\mathrm{MJ})+.017(\mathrm{CD})-.0003(\mathrm{Cl})$ & .90 & .91 & .24 \\
\hline ATWL & $\ln (F)=.51+3.72(\mathrm{AS})+.018(\mathrm{AC})+.044(\mathrm{MJ})-.026(\mathrm{CD})-.0002(\mathrm{Cl})$ & .93 & .94 & .18 \\
\hline ATWH & $\ln (F)=.68+.86(\mathrm{AS})+.026(\mathrm{AC})+.009(\mathrm{MJ})+.043(\mathrm{HT})$ & .87 & .89 & .24 \\
\hline ATTL & $\ln (F)=1.95+1.00(\mathrm{AS})+.023(\mathrm{AC})+.008(\mathrm{MJ})$ & .89 & .90 & .25 \\
\hline ATTH & $\ln (\mathrm{F})=1.89+.027(\mathrm{AC})+.011(\mathrm{MJ})-.005(\mathrm{HT})-.00005(\mathrm{Cl})$ & .88 & .89 & .21 \\
\hline \multicolumn{5}{|c|}{ Highest $R_{\mathrm{a}}^{2}$ models without AS } \\
\hline ATVL & $\ln (F)=.647+.034(\mathrm{MJ})+.031(\mathrm{AC})-.0002(\mathrm{Cl})$ & .88 & .89 & .35 \\
\hline ATVH & $\ln (F)=.311+.037(\mathrm{MJ})+.047(\mathrm{AC})-.0003(\mathrm{Cl})+.017(\mathrm{CD})$ & .90 & .91 & .24 \\
\hline ATWL & $\ln (F)=.322+.048(\mathrm{MJ})+.017(\mathrm{AC})-.0003(\mathrm{Cl})$ & .88 & .90 & .24 \\
\hline ATWH & $\ln (F)=.535+.008(\mathrm{MJ})+.026(\mathrm{AC})+.029(\mathrm{HT})+.025(\mathrm{CD})$ & .84 & .86 & .26 \\
\hline ATTL & $\ln (\mathrm{F})=2.18+.013(\mathrm{MJ})+.019(\mathrm{AC})-.010(\mathrm{HT})+.035(\mathrm{CD})$ & .78 & .82 & .35 \\
\hline ATTH & $\ln (F)=1.89+.011(\mathrm{MJ})+.037(\mathrm{AC})+.005(\mathrm{HT})-.00005(\mathrm{Cl})$ & .88 & .89 & .21 \\
\hline \multicolumn{5}{|c|}{ Efficiency models } \\
\hline ATVL & $\ln (F)=.647+.034(\mathrm{MJ})+.031(\mathrm{AC})-.0002(\mathrm{Cl})$ & .88 & .89 & .35 \\
\hline ATVH & $\ln (F)=.489+.037(\mathrm{MJ})+.050(\mathrm{AC})-.0003(\mathrm{Cl})$ & .90 & .91 & .24 \\
\hline ATWI & $\ln (F)=.322+.048(\mathrm{MJ})+.017(\mathrm{AC})-.0003(\mathrm{Cl})$ & .88 & .90 & .24 \\
\hline ATWH & $\ln (F)=.669+.008(\mathrm{MJ})+.029(\mathrm{AC})+.028(\mathrm{HT})$ & .84 & .86 & .26 \\
\hline ATTL & $\ln (F)=2.37+.008(\mathrm{MJ})+.020(\mathrm{AC})$ & .77 & .78 & .37 \\
\hline ATTH & $\ln (F)=2.18+.004(\mathrm{MJ})+.027(\mathrm{AC})+.004(\mathrm{HT})$ & .88 & .89 & .21 \\
\hline \multicolumn{5}{|c|}{ Best single variable models } \\
\hline ATVL & $\ln (F)=1.96+.021(\mathrm{MJ})$ & .78 & .79 & .47 \\
\hline ATVH & $\ln (F)=1.75+.046(\mathrm{AC})$ & .78 & .79 & .36 \\
\hline ATWL & $\ln (F)=1.43+.027(\mathrm{MJ})$ & .81 & .82 & .30 \\
\hline ATWH & $\ln (F)=1.41+.054(\mathrm{AC})$ & .61 & .62 & .41 \\
\hline ATTL & $\ln (F)=2.54+.032(\mathrm{AC})$ & .69 & .70 & .42 \\
\hline ATTH & $\ln (F)=2.52+.035(\mathrm{AC})$ & .84 & .84 & .24 \\
\hline
\end{tabular}

aF-Forage (g), MJ-Major axis (cm), AS-Average seedhead weight (g), HT-Height (cm), AC-Average cover $(\mathrm{cm})$, CD-Crown depth (cm), Cl-Circular area $1\left(\mathrm{~cm}^{2}\right), \mathrm{MN}-\mathrm{Minor}$ axis $(\mathrm{cm})$. E-Elliptical area $\left(\mathrm{cm}^{2}\right)$. Abbreviations for taxon and form class: ATVL-low use mountain big sagebrush, ATVH-high use mountain big sagebrush, ATWL-low use Wyoming big sagebrush, ATWH-high use Wyoming big sagebrush, ATTL-low use basin big sagebrush, ATTH-high use basin big sagebrush. ${ }^{\mathrm{B}} \mathrm{RMSE}=\mathrm{MSE}^{1 / 2}$.

For ATVL all variables are significant at $P<0.01$ for the efficiency model (Table 1). Dean et al. (1981) developed a regression model for predicting biomass of mountain big sagebrush that included 4 variables with $R^{2}=0.85$. Our efficiency model for ATVL is in close agreement and may be more precise than the model of Dean et al. (1981) which included the variable crown denseness (\%) (along with maximum and minimum diameter and crown depth), which is an ocular estimate and required calibration to insure consistency. Our models use the variable AC. Canopy cover (AC) is preferable as it is a rapid and less subjective technique (Canfield 1941).

The highest $R_{\mathrm{a}}^{2}$ model without AS for ATVH in Table 1 includes 4 variables. But the variable crown depth $(C D)$ is not significant and therefore is excluded from the efficiency model. Thus, the same variables are used as for ATVL.

All 3 variables in the efficiency model for ATWL (Table 1) are significant at the $P<0.05$ level. Again, the same variables are in the model as for ATVL and ATVH. A 1 variable model for ATWL which is based upon MJ explains much of the variation with $R_{\mathrm{E}}=$ 0.81 (Table 1). The major axis (MJ) and canopy cover (AC) alone account for $81 \%$ and $78 \%$ of the variation, respectively. Mountain and Wyoming big sagebrush have similar growth forms in low-use form classes.

The efficiency model for ATWH (Table 1) has 3 variables: MJ, $\mathrm{AC}$, and height (HT), all significant at $P<0.01$. Either $\mathrm{HT}$ or $\mathrm{AC}$ alone accounts for $61 \%\left(R_{\mathrm{a}}^{2}\right)$ of the variation in forage for ATWH. The major axis (MJ) accounts for $53 \%\left(R_{\mathrm{a}}^{2}\right)$ of the variation for the high use form class of Wyoming big sagebrush (ATWH) as compared to $81 \%\left(R_{a}^{2}\right)$ for the low use form class of the same taxon (ATWL).
The efficiency regression model for ATTL resulted in the lowest $R_{\mathrm{a}}^{2}$ value of 0.77 (Table 1). This may be from the very tall growth form typical of unbrowsed basin big sagebrush. Equations with only $\mathrm{MJ}$ and $\mathrm{AC}$ (efficiency model) provide essentially the same information as when HT and CD (both significant at $P<0.10$ ) are added to create the highest $R_{\mathrm{a}}^{2}$ (Table 1). The addition of average seedhead weight (AS) to the 2 variable model results in a substantial improvement both in $R_{\mathrm{a}}^{2}$ and RMSE values. It appears that the increase in field time for collection of (AS) data for ATTL is only justified when a high degree of accuracy is needed.

In the highest $R_{\mathrm{a}}^{2}$ model for ATTH, the circular area (Cl) for the major axis is not significant, therefore, it is omitted from the efficiency model (Table 1). Canopy cover (AC) alone results in a very reliable model with $R_{2}=0.84$.

Difficulties in identifying the big sagebrush subspecies are well known (Winward and Tisdale 1977). Nevertheless, their differentiation is important in analyzing site potential and condition (Dean et al. 1981), identifying animal preferences (Welch and Pederson 1981, Personius et al. 1987), and predicting treatment response. Different regression models for each subspecies greatly increased precision in predicting forage production, thereby demonstrating the value of recognizing subspecies and their respective production potentials. Even though the regression models for ATWL and ATVL use the same variables, the $y$-intercept and the associated coefficients in each model are quite different.

Heavy previous use can be considered a treatment that affects growth form (Patton and Hall 1966). Hughes et al. (1987) found that while range site did not affect regression models, mechanical treatment (shredding) did. Hughes et al. (1987) concluded that treatments that greatly modify plant form will probably require regression models different from those of undisturbed vegetation. 
Our findings are consistent with this premise, as separate regression models were developed by browse form class for each taxon with a significant $(P<0.0001)$ increase in precision. Our consideration of both taxon and form class resulted in significant improvement in the models. This ranged from a $6 \%$ to $13 \%$ increase in the $R_{\mathrm{a}}^{2}$. The RMSE decreased from $10 \%$ to $50 \%$.

If a strict random sampling technique can be applied, a transformation of the independent variables may be avoided, as the error terms would have the same variability (i.e., constant variance). But a stratified sample is often desirable when there are risks that a random sample may not satisfactorily represent the population. We believed this to be the case with determination of annual winter forage production from big sagebrush taxa, emphasized by the short sampling period between ephemeral leaf drop and winter.

Other researchers have developed log-log models for predicting various components of big sagebrush (Rittenhouse and Sneva 1977, Dean et al. 1981). Tausch (1989) determined that systematic bias from log-log transformations with a specified nonlinear model is an important factor to consider in biomass estimation. In this study, linear regression was justified by the fact that nonlinear relationships were not indicated in the scatter plots of dependent versus independent variables.

Our colinearity analysis indicated that the major axis (MJ), minor axis (MN), and elliptical canopy area (E) should not be used in the same model as doing so tends to increase the prediction error and more importantly, invalidates the model selection procedure. Thus, this resulted in somewhat different final regression models than those reported by other researchers. Rittenhouse and Sneva (1977) combined these variables in some of their higher $R^{2}$ models. Dean et al. (1981) also used measures of MJ and MN together in the best-fit models that they reported. These studies do not mention colinearity. If colinearities among $M J, M N$, and $E$ were not indicated for their data, then it would seem that the overall shape of big sagebrush is more variable from site to site than generally known. The colinearity diagnostics determine the appropriateness of including different variables in the same regression model, and increase efficiency by avoiding collection of redundant measurements.

The addition of average seedhead weight (AS) improved the $R_{\mathrm{a}}^{2}$ values in some cases. Although the variable is time consuming to collect, it may be justified in predicting forage production for low-use form classes where seed stalk production is generally high.

A single variable may be adequate to estimate big sagebrush production depending on resources available and acceptable accuracy level. Rittenhouse and Sneva (1977) reported $R^{2}=0.88$ for the longest measure of crown width (MJ) for Wyoming big sagebrush. We also found a strong relationship $\left(R_{\mathrm{a}}^{2}=0.81\right)$ between forage weight (F) and MJ for ATWL (Table 1). However, this variable was not as reliable a predictor of forage for other big sagebrush subspecies (Table 1). The $R_{\mathrm{a}}^{2}$ values with this single variable were consistently low for plants in the high-use form classes.

Canopy cover (AC) in single variable models was found to be quite reliable in all cases (Table 1). This variable is well defined, and easy to collect. Weaver (1986) speculated that a strong relationship between shrub cover and browse mass should allow resource managers to use aerial photographs to estimate available browse.

Regression models are merely useful approximations. Ideally, models should be based on variables that can be measured easily and accurately. Our findings suggest that several easily measured variables can be used in different regression models to accurately predict annual winter forage production for 3 subspecies of big sagebrush in both low and high use browse form classes. We believe our procedure may be applicable on most big sagebrush ranges with similar precision as it accounted for variation in big sagebrush subspecies, size, and browsing history. Our research was conceived from the requests of resource managers and our models should prove useful for management objectives.

\section{Literature Cited}

Andrew, M.H., I.R. Noble, and R.T. Lange. 1979. A non-destructive method for estimating the weight of forage on shrubs. Aust. Rangeland J. 1:225-231.

Beetle, A.A. 1960. A study of sagebrush-the section Tridentatae of Artemisia. Wyoming Agr. Exp. Sta. Bull. 368. Laramie.

Canfield, R.H. 1941. Application of the line interception method in sampling range vegetation. J. Forest. 39:388-394.

Creamer, W.H., C.L. Wambolt, and R.J. Rossi. 1992. Comparison of three groups of variables for prediction of big sagebrush forage production. $p$. 217-221 In: W.P. Clary, E.D. McArthur, D. Bedunah, and C.L. Wambolt, (compilers), Proc.-Symp. on Ecology and Management of Riparian Shrub Communities. USDA Forest Serv. Gen. Tech. Rep. INT-289, Ogden, Ut.

Dean, S., J.W. Burkhardt, and R.O. Meeuwig. 1981. Estimating twig and foliage biomass of sagebrush, bitterbrush, and rabbitbrush in the Great Basin. J. Range Manage. 34:224-227.

Harvey, S.J. 1981. Life history and reproductive strategies in Artemisia. M.S. Thesis, Montana State Univ. Bozeman.

Hughes, G., L.W. Varner, and L.H. Blankenship. 1987. Estimating shrub production from plant dimensions. J. Range Manage. 40:367-369.

Kelsey, R.G., M.S. Morris, and F. Shafizadeh. 1976. The use of sesquiterpene lactones as taxonomic markers in the shrubby species of Artemisia (section Tridentatae) in Montana. J. Range Manage. 29:502-505.

Miller, R.F., and L.M. Schultz. 1987. Development and longevity of ephemeral and perennial leaves on Artemisia tridentata Nutt. ssp. wyomingensis. Great Basin Natur. 47:227-230.

Morris, M.S., R.G. Kelsey, and D. Griggs. 1976. The geographic and ecological distribution of big sagebrush and other woody Artemisias in Montana. Proc. Montana Acad. Sci. 36:56-79.

Murray, R.B., and M.Q. Jacobson. 1982. An evaluation of dimension analysis for predicting shrub biomass. J. Range Manage. 35:451-454

Neter, J., W. Wasserman, and M.H. Kutner. 1985. Applied linear statistical models. 2nd ed. Richard D. Irwin, Inc., Homewood, Ill.

Patten, D.T. 1993. Herbivore optimization and overcompensation: does native herbivory on western rangelands support these theories? Ecol. Appl. 3:35-36.

Patton, A.J., and D.F. Hall. 1966. Evaluating key browse areas. J. Wildl. Manage. 30:477-480.

Pechanec, J.F., and G.D. Pickford. 1937. A weight estimate method for determination of range or pasture production. J. Amer. Soc. Agron. 29:894-904.

Peek, J.M. 1970. Relationship of canopy area and volume to production of three woody species. Ecology 51:1098-1101.

Personius, T.L., C.L. Wambolt, J.R. Stephens, and R.G. Kelsey. 1987. Crude terpenoid influence on mule deer preference for sagebrush. $\mathrm{J}$. Range Manage. 40:84-88.

Rittenhouse, L.R., and F.A. Sneva. 1977. A technique for estimating big sagebrush production. J. Range Manage. 30:68-70.

Striby, K.D., C.L. Wambolt, R.G. Kelsey, and K.M. Havstad. 1987. Crude terpenoid influence on in vitro digestibility of sagebrush. J. Range Manage. 40:244-248.

Tausch, R.J. 1989. Comparison of regression methods for biomass estimation of sagebrush and bunchgrass. Great Basin Natur. 49:373-380.

Uresk, D.W., R.O. Gilbert, and W.H. Rickard. 1977. Sampling big sagebrush for phytomass. J. Range Manage. 30:311-314.

Wambolt, C.L., and A.F. McNeal. 1987. Selection of winter foraging sites by elk and mule deer. J. Environ. Manage. 25:285-291.

Weaver, T. 1977. Area-mass relationships for common Montana shrubs. Proc. Montana Acad. Sci. 37:54-58.

Weaver, T. 1986. Estimation of Cercocarpus ledifolius biomass and leaf area index: three methods. Proc. Montana Acad. Sci. 46:67-75.

Welch, B.L., and J.C. Pederson. 1981. In vitro digestibility among accessions of big sagebrush by wild mule deer and its relationship to monoterpenoid content. J. Range Manage. 34:497-500.

Winward, A.H. 1970. Taxonomic and ecological relationships of the big sagebrush complex in Idaho. Ph.D. Thesis, Univ. Idaho, Moscow.

Winward, A.W., and E.W. Tisdale. 1977. Taxonomy of the Artemisia tridentata complex in Idaho. Univ. Idaho. College Forest., Wildlife, and Range Sci. Bull. 19. 